\title{
How to walk the talk? Developing actions for sustainability in academic research
}

\author{
Jean Hugé ${ }^{\mathrm{a},{ }^{*}}$, Thomas Block ${ }^{\mathrm{b}}$, Tom Waas ${ }^{\mathrm{b}}$, Tarah Wright ${ }^{\mathrm{c}}$, Farid Dahdouh-Guebas ${ }^{\mathrm{a}}$ \\ a Systems Ecology \& Resource Management Lab, Université Libre de Bruxelles, Avenue Franklin Roosevelt 50, 1050 Brussels, Belgium \\ b Centre for Sustainable Development, University of Ghent, Poel 16, 9000 Gent, Belgium \\ ${ }^{c}$ Dalhousie University, Life Sciences Centre, Halifax, Canada
}

\section{A R T I C L E I N F O}

Article history:

Received 16 December 2015

Received in revised form 27 May 2016

Accepted 1 July 2016

Available online 14 July 2016

\section{Keywords:}

Sustainability

Academic research

Workshop

Sustainability science

\begin{abstract}
A B S T R A C T
Sustainability in higher education is a growing field of reflection and practice, yet integrating sustainability and academic research (as a distinct pillar of academia - next to education, societal service and campus operations) is still considered a challenge. This study: i. Proposes a conceptualization of sustainability in academic research based on an explorative literature review; ii. Suggests a range of actions fostering sustainability in academic research based on an expert-based workshop; and iii. Critically reflects on a case study entailing a university-wide sustainability transition initiative. The proposed conceptualization of sustainability in academic research is shaped by the diversity of perspectives in the scientific literature and focuses on the degree of disciplinary integration within and outside academia. Actions to foster sustainability in academic research include actions with regard to: i. Research funding; ii. Research \& career evaluation; iii. Research organization; iv. Capacity building and v. policy. The emerging range of possible actions as designed by research managers as well as the early experience of individual higher education institutions in experimenting with sustainability in academic research contribute to the translation of sustainability into a range of tangible and realistic research actions for higher education institutions.
\end{abstract}

๑) 2016 Elsevier Ltd. All rights reserved.

\section{Introduction}

Sustainability is heralded worldwide as an idea, a process, a strategy and/or an objective that allows to address the current situation of concatenated ecological, social and economic crisis, labeled together as 'global change' (Biggs et al., 2011). The modern, formal and most widely disseminated conceptualization of sustainability originated in the wake of what is commonly known as the Brundtland Report (World Commission on Environment and Development, 1987). While the intergovernmental United Nations milestones contributed to the creation and the maintenance of the global sustainability momentum (as exemplified by the recently adopted Sustainable Development Goals (UN, 2015) and summarized by Quental et al. (2009)), the sustainability concept is shaped, used and 'owned' by an ever-widening range of stakeholders (Hopwood et al., 2005). This democratization of sustainability is a positive evolution as it testifies to the power of attraction and the

\footnotetext{
* Corresponding author.

E-mail address: Jean.Huge@ulb.ac.be (J. Hugé)
}

enduring relevance of the concept (Hugé et al., 2013). The diversity of stakeholders engaging with sustainability gives rise to a multitude of interpretations, ranging from the status quo to reformist and radical agendas (Hopwood et al., 2005). Hence it is difficult to pinpoint any hypothetical exact definition of sustainability. This 'constructive ambiguity' (Robinson, 2004) makes the concept flexible, as it can be translated in a range of actions adapted to the needs and possibilities of a diverse set of stakeholders. Sustainability principles (e.g. normativity, equity, integration etc.) have been proposed in order to avoid trivial conceptualizations and in order to make the dynamic interpretational limits of the concept tangible (Waas et al., 2011). Recently, Griggs et al. (2013) proposed a working definition for sustainability, which we adopt as a basis for discussion: 'development that meets the needs of the present while safeguarding Earth's life-support system, on which the welfare of current and future generations depends'. It is not our intention to close the debate on the interpretation of sustainability, which is often synthesized as a conflict and/or continuum between strong and weak sustainability (Dietz and Neumayer, 2007). We see sustainability as a concept whose sense is given by its relevant usage (Lafferty and Meadowcroft, 2000). If sustainability is to move 
beyond the gap between rhetoric and action, it should become a decision-guiding strategy, defined as a way forward to make happen a desired future (Hugé et al., 2013; Pope et al., 2004).

Higher education institutions have always been actors of change and innovation in society (Beynaghi et al., 2014; Peer and Stoeglehner, 2013; Ramos et al., 2015), and the call and quest for sustainability has found fertile ground in campuses, journals and curricula all over the world. Higher education institutions and researchers have a critical role to play in creating a sustainable future, as they educate many of the professionals who lead, manage, and teach in our society (Khalili et al., 2015; Wittmayer and Schäpke, 2014). Moreover they can be sustainability innovators through research activities and act as models for the community (Wright and Wilton, 2012). A multitude of initiatives have emerged in highly differentiated contexts, ranging from the inclusion of sustainability in mission and vision statements to greenhouse gas reduction programs (Ramos et al., 2015). International declarations have been produced in an effort to guide higher education institutions in integrating sustainability in their institutional dimensions (Lozano et al., 2014; Sylvestre et al., 2013).

The reflections on the roles and processes engaging higher education institutions in sustainability have even led to the emergence of a new field, called 'sustainability in higher education' (Wals and Jickling, 2002). Sustainability in higher education is intrinsically multidimensional but is often represented pragmatically as consisting of four key components: i. Making campus operations more sustainable (e.g. reducing the ecological footprint of a campus, waste management etc.); ii. Learning and teaching for sustainability (e.g. integrating sustainability in curricula); iii. Integrating sustainability in research; and iv. External operations (e.g. the provision of services to society through partnerships with governmental and non-governmental actors (Hoover and Harder, 2015; Waas et al., 2011). Often efforts are concentrated on only one of these dimensions at a time, which is motivated in part by an understandable risk reduction strategy aimed at preventing the ineffective dispersal of scarce resources such as time and funds, but which carries with it the risk to focus only on quick and easy fixes to a higher education system that remains largely unchallenged. While we are aware of this risk of compartmentalization of sustainability efforts (Ramos et al., 2015), this study focuses on one specific component, i.e. the integration of sustainability in research. The integration of sustainability (in one way or another) into research has been comparatively neglected and remains underrepresented in the scholarly literature (Waas et al., 2010). This is not due to a lack of attention devoted to research strategies yet it can be attributed to the difficulties of grasping what sustainability means for existing and new research initiatives, both fundamental and applied. This challenge is closely linked to the more fundamental discussion centred on the conceptualization of 'science for sustainability', which is interpreted by Müller (2003) as science performed in a solution-oriented context of social relevance. In order to clarify this discussion and in order to provide suggestions for implementation, this study aims to:

- Contribute to conceptualizing 'sustainability in academic research';

- Suggest a range of actions that could contribute to the integration of sustainability in academic research;

This is done this in three ways. First, a review of the scientific literature regarding science for sustainability is performed, in order to conceptualize 'sustainability in academic research'. Second, the process and findings of a workshop aimed at compiling a set of possible actions to integrate sustainability in research is presented, at the level of Belgian (Flemish) higher education institutions.
Third, a university-specific initiative in which sustainability was integrated in research is presented.

\section{Methods}

This section describes the methods followed for the literature review, the workshop and the case study.

\subsection{Literature review}

In order to better understand what is meant by sustainability in academic research, an explorative review of the scientific literature was performed with a focus on the characteristics of sustainability science and research for sustainability.

Given the lack of a narrowly defined field (sustainability science and -academic- research for sustainability being broad concepts relevant to an equally broad range of authors and readers), a fully comprehensive literature review was not possible. Inspired by the 'integrated literature review' approach (Kohtala, 2015), this literature review aims at synthesizing the knowledge from diverse sources and aims at portraying a complex concept through a diverse and broad sampling frame instead of producing a complete compendium of the literature. Hence references are drawn from a wide range of relevant journals. Furthermore, three journals were targeted for a targeted systematic literature review: the Journal of Cleaner Production, Sustainability Science, and the International Journal of Sustainability in Higher Education. The three journals used for the systematic literature review were consciously selected as they cover sustainability in academic research in complimentary ways. Together, these journals provide a dynamic vision on what sustainability science entails (Sustainability Science), on the conceptualization and challenges with regard to sustainability in higher education (Journal of Cleaner Production), and on initiatives taken in a variety of higher education institutions (Journal of Sustainability in Higher Education). Use of the keywords 'academic' AND 'research' (jointly present) in the search engines of each journal yielded respectively 1175 (Journal of Cleaner Production) 133 (Sustainability Science) and 436 (International Journal of Sustainability in Higher Education) hits. All articles' titles and abstracts were subsequently screened and articles that were considered relevant for this study's literature review were used. The selected body of literature was analyzed qualitatively. The findings of the literature review are synthesized in Section 3, and focus on the context of sustainability challenges, the conceptualization of sustainability science and the translation into academic research for sustainability.

\subsection{Workshop}

The findings of the literature review were summarized in a draft synthesis note introducing 'science for sustainability' and offered to an audience of research managers, research \& development units and research unit leaders in all the higher education institutions (universities and colleges) of Flanders, Belgium's northern region. This note was drafted at the request of the regional Flemish government's Department of Nature, Energy \& Environment's EcoCampus Unit. Having received this synthesis note, representatives from every higher education institution in Flanders were invited to a one-day workshop in Brussels in March 2015. The purpose of the workshop was twofold: first the workshop aimed to gather information from participants regarding their perceptions and comments on science and research for sustainability; second, the workshop was action-oriented and aimed at listing a range of possible actions that may facilitate the realization of research for sustainability in Flemish higher education institutions. Participants 
were personally invited to attend the workshop. Every research \& development unit of every Flemish higher education institution was invited to send at least one representative. Additionally, some participants were purposively selected based on their expertise in research for sustainability. The participants included research managers $(n=10)$, research unit leaders $(n=3)$ and individual researchers \& experts $(n=5)$. A total of 18 people attended the workshop as participants. Participants came from a variety of disciplinary backgrounds including sociology, engineering, economics and political sciences. The focus group method was used. A focus group is a planned discussion among a small group of people facilitated by a skilled moderator (in our case the lead author) (Waas et al., 2010). A focus group is designed to obtain information about people's preferences and values with regard to a defined topic and why these are held, by observing the structured discussion of an interactive group in a permissive, non-threatening environment. The key characteristic is that participants react and interact with each other (Scott, 2011). Focus groups are suited for the exploration of a concept and aim at generating creative ideas. In this study, the focus group participants were asked to propose a range of actions that could facilitate the development and realization of research for sustainability in Flemish higher education institutions. After a brief introduction by the moderator, the participants were invited to reflect -in a plenary setting-on the linkages between sustainability and academic research. They were then asked to think of possible actions that could realistically be implemented in their respective institutions, by working in four sub-groups. Participants were asked to write down proposed actions during their discussions. Synthesizing the interview data into a set of possible actions inevitably involves a degree of interpretation. In order to ensure the transparency and traceability of the interpretation by the interdisciplinary team of authors, all interviews were transcribed and subsequently coded for recurrent terms and ideas. The data was analyzed using qualitative open coding (as done by Waas et al. (2010) and by Hoover and Harder (2015). Open coding aims to open up the data to as much potential as possible in order to 'discover', in this case to identify a number of actions. No pre-elaborated coding list was imposed on the data, instead the data was coded in an emergent way, i.e. starting from the data. Through constant comparisons, similar data were grouped and each group - representing a -series of-actionswas named. Finally, a plenary session at the end allowed the participants to exchange views and give feedback on the proposed actions. The proposed actions of all subgroups were projected on a screen during the plenary discussion. A draft report of the workshop was subsequently prepared and sent out to all participants who had the opportunity to give feedback. The findings of the workshop are presented in Section 4.

\subsection{Case study}

In order to compliment the literature review and the workshop with a reflection on a practical experience in fostering sustainability in academic research, a desk study on Ghent University's Sustainability Transition Initiative was performed. Ghent University was chosen for three main reasons: i. It is the only Belgian higher education institution that has launched a systematic and university-wide initiative to integrate sustainability in academic research, through the Ghent University Transition Initiative (Ghent University, 2014; Sustainability Exchange, 2015); ii. Ghent University is the second largest Belgian university in terms of number of students (41,000 students spread over 17 faculties) and consistently ranks within the top three of Belgian universities (Ghent University, 2015), and hence is a key actor in the Belgian higher education landscape; iii. The city of Ghent's initiatives regarding sustainability (including the city's climate neutrality ambition for 2050 (Nevens and Roorda, 2014) and numerous sustainable urban projects (Devolder and Block, 2015)) provide an interesting context for potential synergies between the university and non-academic actors.

\section{Results of the literature review: sustainability in academic research}

\subsection{The context}

As sustainability has retained its appeal for now, the concept can only be of practical use if seen as a strategy to guide decisions. If sustainability is to be 'implementable', it should be a strategy - a way forward to make a desired future happen. Generating and managing knowledge is essential to realize the ambition of sustainability as a strategy to guide decisions. A decision-guiding strategy gains its legitimacy through the knowledge that forms the base of the strategy itself. This knowledge should be able to deal with complexity, uncertainty and multiple legitimate value-laden viewpoints - as these are the three key context-defining features of any sustainability challenge (Hugé et al., 2013). For a better understanding of the type of knowledge needed to implement sustainability, one has to keep in mind the context in which sustainability is to be achieved.

\subsection{Complexity}

Sustainability issues are intrinsically linked to each other and the many interactions between social and natural systems are of high and increasing complexity (Ostrom, 2009; Wuelser et al., 2012). Complex issues concern a web of related problems, lie across or at the intersection of many disciplines and the underlying processes interact on various temporal and scale levels (Van Asselt and Rijkens-Klomp, 2002). Complex issues involve a large variety of technical and scientific input as well as important value-laden and ethical aspects (Andersson, 2008). Indeed the interplay between environmental processes and human activity, and the values underlying the perspectives on this interplay are key in any sustainability issue. Issues such as climate change, loss of biodiversity, resource depletion, poverty traps etc. prove difficult to solve. Their consequences are far-reaching yet unpredictable. Expert knowledge is incomplete, fragmented, and uncertain, giving rise to scientific controversies. Furthermore, social and political controversy arises because of a lack of agreement on norms and values at stake and on the acceptability of goals and solutions. In short, complexity applies to systems showing deep uncertainties and a plurality of legitimate perspectives (Funtowicz et al., 1999). Studying sustainable development consequently entails studying non-linear causal networks, emerging issues and recognizing limitations in understanding (Ostrom, 2009).

Complexity is present at various levels: First, the intrinsic complexity of multidimensional societal challenges is creating an ever-growing need for information and debate (Funtowicz et al., 1999). Complexity is closely related to the ever-increasing size and pace of information flows that submerge decision-makers. In other words, today's world is arguably 'messier now than it was in earlier decades' (Rosenau, 2005). Rosenau (2005) speaks of 'fragmegration' (a neologism combining fragmentation and integration) to denote today's world's complexity and identifies eight complexity-enhancing forces ranging from microelectronic technologies to authority crises and to economic globalization.

Secondly, institutional complexity arising from the new realities of multilevel governance networks blurs the boundaries between the responsibilities and competences of 'classical' jurisdictional entities such as the nation-state and -new- players such as regions, 
stakeholder groups and multilateral organizations. Complexity is now also a defining feature of sustainable development governance (Jänicke, 2007). This means that in order to understand the sustainability of complex systems, multilevel nested frameworks are needed (Ostrom, 2009). As 'the price of increased complexity is pervasive uncertainty' (Gibbons, 1999) we will now delve deeper into the latter.

\subsection{Uncertainty}

The context into which knowledge for sustainability needs to be generated and used in order to cope with global change is characterized by inherent uncertainty. Uncertainty is a key feature of sustainability (Boulanger and Bréchet, 2005), which is by definition a future-oriented concept. Uncertainties have become more significant in recent times because of the growing scope, complexity and hazardous consequences of human activities. Complex systems such as ecosystems and social systems are difficult to predict. Newman (2006) introduces the term 'incredible uncertainty': not only are we unable to predict the consequences of events, we are also unable to predict which events are the ones that will lead to future change. The interactions between the socio-economic system and the environment are mostly characterized by strong uncertainty as global sustainability problems have no historical precedent (Steffen et al., 2011). In addition, uncertainty also challenges the formerly self-evident authority of knowledge providers such as academics (Funtowicz et al., 1999). In order to deal with uncertainty, a learning approach and a high adaptive capacity are required.

\subsection{Values \& multiple legitimate viewpoints}

Within the interpretational limits of sustainable development, many legitimate viewpoints co-exist (Hopwood et al., 2005), which often reflect particular values. Values are beliefs about goals in life that are desirable for an individual or for society (Andersson, 2008). Values lead to different perspectives, which differ between various actors. Some values are shared by almost everyone while others are cultivated within certain social groups. These perspectives reflect personal agendas as well as particular political, cultural or historical sensitivities and materialize for instance through differences in emphasis regarding the dimensions of sustainability. Decisionmaking for sustainable development hence not only requires scientifically valid knowledge but also knowledge that is acceptable to various societal actors (Runhaar, 2009; Wuelser, 2014). Hence stakeholder input is needed to provide knowledge (Runhaar, 2009). Blanchard and Vanderlinden (2010) also refer to these multiple viewpoints from a disciplinary point of view: scientific disciplines have become so specialized that coherence is lost. 'No perspective is wrong by its own measures, however, they are all incomplete without the other perspectives'. Knowledge for sustainable development needs to propose solutions to deal with these legitimate viewpoints.

The recognition of the importance of the three context-defining characteristics described above has consequences for knowledge generation for sustainable development. It has even led to the emergence of 'new' forms of science, which we group under the heading of 'science for sustainability'.

\subsection{Science for sustainability}

Sustainability's normative character, its long-term horizon and the context in which sustainability challenges are to be addressed, result in specific demands for science (Funtowicz et al., 1999). A new concept of science, different from disciplinary, normal science seems to be necessary (Müller, 2003). In the context of sustainability, 'knowledge creation' is more than the rational, cognitive and technical procedures of science as previously understood. Instead knowledge creation is perceived as a process or practice (Zanotti and Palomino-Schalscha, 2016). Science for sustainability is defined by the problem it addresses rather than by the disciplines it employs (Clark, 2007; Wiek et al., 2011). These problems are increasingly characterized and interpreted as so-called 'wicked' problems (Wiek et al., 2011). Wicked problems are unstructured, meaning that: i. There is uncertainty regarding the knowledge base on which to solve these problems; and ii. There is disagreement on norms and values (Dentoni and Bitzer, 2014; Hoppe, 2010; van Zeijl-Rozema et al., 2008). These wicked problems (which include most aspects of e.g. climate change, biodiversity loss and societal inequality) can only be understood in a context of complexity, uncertainty and diversity of values. Fig. 1 (freely inspired by Hoppe, 2010) schematically visualizes the variety of problems science can deal with.

Next to the problem-based approach and the societal relevance of science for sustainability, multiple types of knowledge for sustainability need to be acknowledged (Grist, 2008; Miller et al., 2014). These 'knowledges' include: i. Diagnostic knowledge (with regard to the causes leading to 'un-sustainability); ii. Explanatory knowledge (with regard to the interactions between social activities and sustainability impacts); iii. Orientation knowledge (with regard to normative justification arguments); iv. Knowledge for action (with regard to finding solutions to 'un-sustainable' situations (Wooltorton et al., 2015)).

Knowledge for sustainability needs to analyze a system's deeper-lying structures, (diagnostic and explanatory knowledge), it needs to project into the future (orientation knowledge), it needs to assess the impact of decisions (explanatory, orientation and action knowledge), and it has to lead to new strategies for solutions (knowledge for action) (Miller et al., 2014; Waas et al., 2010).

Science for sustainability is used here as a generic term to describe science performed in a solution-oriented context of social relevance (as in e.g. Müller, 2003), characterized by complexity, uncertainty and the importance of values. Scholars have proposed specific terminology describing its characteristics, including: mode 2 science (Nowotny et al., 2003; Hessels and van Lente, 2008); post-

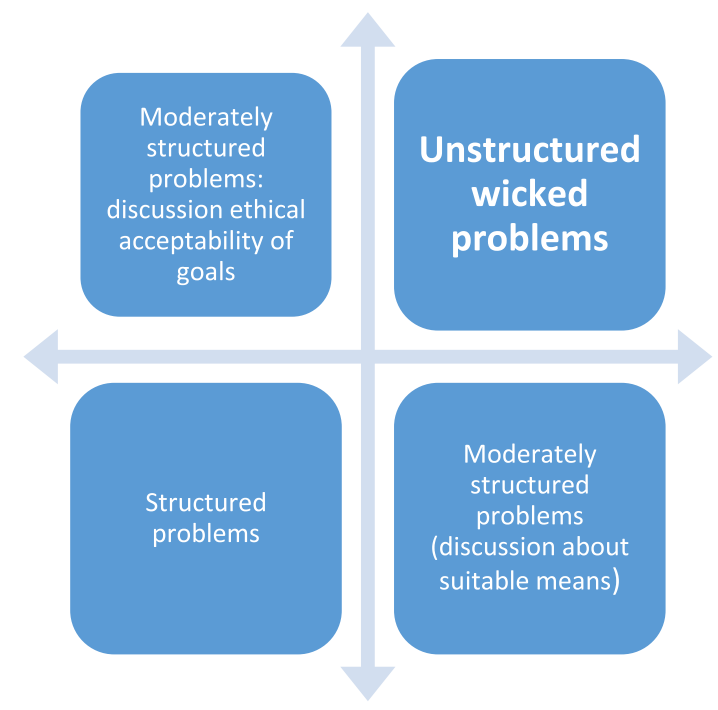

Fig. 1. Typology of problems based on the degree of certainty of knowledge and the degree of agreement on values. The $\mathrm{X}$ axis represents a continuum of increasing uncertainty on the required knowledge (uncertainty highest on the right end). The Y axis represents a continuum of agreement on norms and values (agreement highest at the bottom). 
normal science (Funtowicz et al., 1999); and sustainability science (Clark, 2007; Friibergh Workshop on Sustainability Science, 2000; Kemp and Martens, 2007; Popa et al., 2015). Despite differences in formulation and emphasis, these approaches essentially describe the same content (summarized in Table 1). Science for sustainability (used here as an umbrella term including key elements of mode 2 science, post-normal science and sustainability science) aims at the integration of different disciplines, viewpoints and knowledge types (Kemp and Martens, 2007) and calls for a 'new approach to science'. Science for sustainability is an 'evolving process of knowledge construction requiring co-operation between disciplines to arrive at a shared understanding of issues at hand' (Blanchard and Vanderlinden, 2010). Hulme and Toye (2006) speak of 'knowledge communities' instead of disciplines. They argue that what matters is consensus on aims and methods within the community. Furthermore as knowledge will always be provisional and incomplete in its descriptive aspects, as well as depending on changing normative expectations, sustainability science needs to be reflexive, i.e. sensitive to the way in which knowledge was generated - and hence to what the underlying uncertainties are. In summary, sustainability science builds on both normative and positive inputs: the new scientific paradigm is no longer exclusively based on 'objectivity', but also incorporates normative elements (Luks and Siebenhüner, 2007). Sustainability needs to be designed and implemented using science (the most authoritative source of facts about reality) and deliberate human choices motivated by values (Sabau, 2010). Alternative problem framings are essential and can lead to 'out of the box' thinking and to the realization of innovative solutions to respond to complex societal challenges.

Table 1 presents a synthetic overview of the characteristics of science for sustainability, based on a critical synthesis of the literature (including Baumgartner, 2011; Clark, 2007; Kastenhofer et al., 2011; Kemp and Martens, 2007; Lang et al., 2012; Luks and Siebenhüner, 2007). Multi- and interdisciplinary research refer to the conceptual and methodological collaboration between scientific disciplines, while trans-disciplinarity refers to the inclusion of non-academic actors. This approach embodies the idea of coproduction of knowledge and is closely linked to the recognition of own limitations and assumptions. Normative and positive inputs refer to the necessary acknowledgement of values and facts - the collective confrontation of various interpretations of sustainability being key. Socially robust knowledge aims to combine the reliability and credibility of scientific knowledge with the democratic procedures of representation and decision by compromise (Nowotny et al., 2001). The exploratory character of science for sustainable development and the attention devoted to system innovation and transition are linked to the solutions-orientation of this approach to science.

\subsection{The implementation challenge: conceptualizing research for sustainability}

While there is a convergence on views on what conceptually

Table 1

Characteristics of science for sustainability.

Multi, inter- and transdisciplinary research

Co-production of knowledge

Normative \& positive inputs

Systemic integration

Exploratory character

Recognition of own limitations \& assumptions

Contextual knowledge

Learning-oriented perspective

Production of socially robust knowledge

Attention to system innovation \& transition defines science for sustainability (Section 3.2), the consequences for research -defined here as the systematic gathering of information-are less clear-cut. Science refers to a contextually useful ordering of information flows. Research is a key step in the production of science. Without elaborating on semantics, at this stage it is sufficient to state that research is about the realization of the somewhat abstract scientific concepts. In other words: what does sustainability science mean for researchers and the institutions they work for? How can the transformational potential of the characteristics outlined in Table 1 be realized in practice?

The shared diagnosis with regard to 'wicked problems' and their characteristics, the recognition of the urgent need to take action (as stated in international reports such as IPCC (2014) and the Millennium Ecosystem Assessment (2005), and as voiced in the many declarations on sustainability in higher education (Sylvestre et al., 2013)), combined with the enduring relevance of the sustainability concept, point to the need to transform the way academic research is thought, organized and performed (Lang et al., 2012). Yet how are higher education institutions supposed to do that? Although laudable initiatives exist, there has been no significant inversion of unsustainable global trends yet (Steffen et al., 2015).

The rising recognition of the characteristics of science for sustainability not only led to new concepts (see Section 3.2), but also to new interdisciplinary academic fields such as ecological economics, technology assessment and science \& technology studies (Kastenhofer et al., 2011). In practice however these fields' research approaches do not always live up to the expectations regarding clear societal recommendations (Clark, 2007; Kastenhofer et al., 2011; Schoolman et al., 2012), indicating that 'performing' science for sustainability is still a challenge.

While initiatives such as Future Earth (www.futureearth.org/) embody the global 'science for sustainability' momentum and while adaptive and innovative research agendas are emerging (Miller, 2013; Miller et al., 2014), some scholars and higher education institutions may fail to see the wood for the trees. Scholars may become intimidated by the growing gap between discourse and action, and between -perceived- frontrunners and laggards in adopting and implementing the principles of science for sustainability in their research. Keeping up to date with the rapidly evolving science for sustainability movement, while simultaneously striving to achieve academic excellence -which often means focusing on a specific research niche-is a challenge. This study aims at translating science for sustainability into actions that can be undertaken by higher education institutions within their own reach of action.

A first step in this 'translation' endeavor is to recognize that no single higher education institution starts from scratch. There is a huge amount of sustainability-relevant research going on within the existing academic disciplines, while there is also a growing awareness of the need for a more transformative, complementary approach to address current sustainability challenges (Aktas, 2015; Clark, 2007; Costa and Scoble, 2006; Gardner, 2013; Jain et al., 2013; Perrings, 2007). Implementing these transformative approaches to research is not an easy task though, and many obstacles are in place, ranging from career incentives and funding issues to leadership and cultural issues (Ferrer-Balas et al., 2010; Waas et al., 2010). The next sections, focusing on the workshop and on the case study, aim at clarifying what sustainability in academic research may actually entail.

Scholars and actors of science policy agree on the need to go beyond mere description and analysis in doing research. Research should also be transformative: 'Transformative research is needed so that sustainable pathways can be explored and taken'. Hence research for sustainability can be defined as problem-driven, solutions-oriented, societally relevant research (Miller et al., 2014; 
Müller, 2003). This means that many scholars are already performing research for sustainability albeit they may not be aware of it. Fig. 2 provides an outline of what research for sustainability entails. This -consciously open-representation reflects the continuum of perspectives on the implementation science for sustainability by performing academic research.

Research for sustainability includes sustainability-relevant mono-disciplinary research (e.g. on the technicalities of the development of effective, less carbon-intensive motor engines), multi- and inter-disciplinary research entailing increasing degrees of interconnectedness between scientists, and trans-disciplinary research which entails the inclusion of non-academic actors and their knowledge(s) (Brandt et al., 2013). While every type of research in Fig. 2can contribute to solve sustainability challenges (including the essential disciplinary research components), the more one moves towards the right end of the continuum, the greater the potential for truly integrative and systemic approaches that will allow to address large-scale sustainability challenges (Binder et al., 2015; Stock and Burton, 2011) and the greater the chance that the characteristics of science for sustainability will be translated into concrete research actions.

Transdisciplinary research has the greatest potential to yield coproduction of socially robust knowledge, and to enlarge the community by creating new relevant knowledge (Binder et al., 2015; Cornell et al., 2013; Gaziulusoy et al., 2015; Jasanoff, 2004; Lang et al., 2012; Lukman et al., 2009; Manring, 2014; McCormick et al., 2016; Posch and Scholz, 2006; Polk, 2014; Trenchner et al., 2013; van Breda et al., 2016).

In practice, research for sustainability requires a willingness to adopt a flexible and eclectic approach when choosing research methodologies, paradigms (Fien, 2002) and actions (see Section 4). The diversity of perspectives on research for sustainability is matched by different degrees of interconnectedness between research and the other dimensions of sustainability in higher education. Performing inter- or trans-disciplinary research presupposes adequately trained researchers with a sustainabilityminded educational trajectory.

Despite the need for adjustments and for ongoing dialogue in order to overcome jargon differences (Sauvé et al., 2015), and despite the fact that common frameworks for knowledge gathering in transdisciplinary research are not ready-made (Brandt et al., 2013), integrative frameworks such as Ostrom's sustainability assessment scheme for socio-ecological systems (Ostrom, 2009) provide key starting points for organizing and performing sustainability research in practice. Kates et al. (2001) provide a range of core questions and themes on which sustainability research should focus, including: 'How can society most effectively guide or manage human environment systems toward a sustainability transition?'

Section 4 and 5 are concerned with the implementation challenge, and hence with turning research for sustainability into a range of concrete actions.

\section{Results of the workshop: research actions for sustainability}

Recognizing the diversity of views on sustainability inside

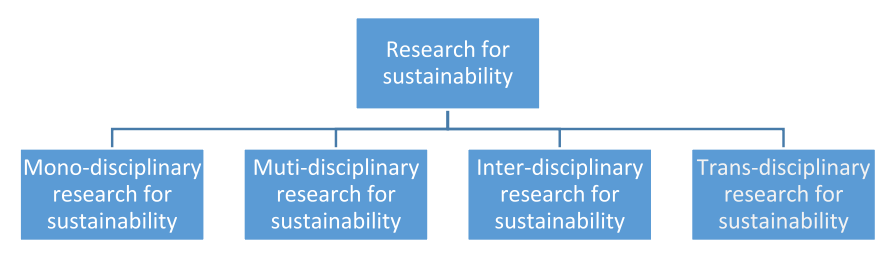

Fig. 2. Research for sustainability as a continuum of research approaches. higher education institutions (Sylvestre et al., 2014; Wright and Wilton, 2012), and acknowledging both the depth and the breadth of current literature on sustainability science and its operationalization into research objectives, programs and indicators, this section is based on a participatory exercise. A blueprint approach for operationalizing research for sustainability is not desirable and not feasible (given the wide range of interpretations and context-specificities in various higher education institutions), yet the findings of the workshop provide an example of possible actions as proposed by research managers and other academics in Flanders, Belgium.

These actions are a shared responsibility between the higher education institutions (and their research teams), the government and other research-funding organizations. The diversity of research funding mechanisms and cultures among and between jurisdictions (countries, states, regions) is huge, which makes it impossible to provide a detailed chain of responsibilities. However even levers of action that are not under direct control of the higher education institutions can be mobilized by advocacy and transparent lobbying.

Table 2 provides a selection of possible actions that can stimulate and integrate research for sustainability in higher education institutions. All workshop participants were provided with a synthesis of the literature review on academic research for sustainability to feed the debate. The proposed actions were all suggested by the workshop participants, and are based on the outcomes of the March 2015 workshop in Brussels, Belgium. The actions are divided as follows: i. Research funding actions; ii. Research and career evaluation actions; iii. Actions regarding research organization; iv. Capacity building actions; v. policy actions.

\section{Case study: steps towards research for sustainability at Ghent University, Belgium}

Ghent University (UGent) is one of the largest Belgian universities (41,000 students, 9000 staff members and 117 research units spread over 17 faculties). Since 2012, a group of frontrunners consisting of professors and students has initiated a bottom-up process to foster sustainability at the university. This process has been strongly supported by the university's Environmental Coordination Unit and by its Centre for Sustainable Development. Ultimately, the initiative has been actively supported by the main governing bodies too. This initiative, known as "Transition UGent' (or the Ghent University Transition Initiative)' (Sustainability Exchange, 2015) is now a think tank as well as an open network, and it has produced two 'Memorandums' (in March 2013 and October 2014). At the moment, Transition UGent engages over 250 academics, students and people from the university management in suggesting objectives and actions for the sustainability policy of Ghent University.

The transition approach to sustainability presents societal transformation as the interplay between different levels: the landscape level describes the exogenous drivers (e.g. climate change, globalization), the regime describes the dominant state of the socio-technical system (e.g. the energy system or food system, which consists of several dimensions: science, culture, policy, industry, markets, technology) and the niches, which are innovative spaces and initiatives that can trigger changes at the regime (Geels, 2002). According to this multi-level perspective, the momentum for a transition grows under a combination of increasing landscape pressures, internal regime contradictions and the development of promising niches. This descriptive approach served as a general framework within 'Transition UGent' To effectively start making Ghent University more sustainable, the transition management approach was used (Loorbach, 2007). This approach suggests 
Table 2

List of possible 'research for sustainability'-actions (based on the March 2015 workshop with research managers in Flanders, Belgium).

\begin{tabular}{|c|c|c|}
\hline Type of action & Objective & Actions \\
\hline $\begin{array}{l}\text { Research } \\
\quad \text { funding }\end{array}$ & - Financial support for research for sustainability; & $\begin{array}{l}\text { - Valorizing a sustainability focus in project proposals (e.g. by allocating extra funds); } \\
\text { - Funding interdisciplinary research platforms/hubs; } \\
\text { - Funding interdisciplinary pilot studies (e.g. scenarios w.r.t. Specific societal challenges); } \\
\text { - Funding interdisciplinary PhD scholarships; } \\
\text { - Funding full time tenure track professors in sustainability science; } \\
\text { - Adjustment of allocation criteria of the higher education institution's research fund; } \\
\text { - (Inter-)faculty financial incentives (e.g. in support of inter-disciplinary project proposals); }\end{array}$ \\
\hline $\begin{array}{l}\text { Research \& } \\
\text { career } \\
\text { evaluation }\end{array}$ & $\begin{array}{l}\text { - Integration of aspects of research for sustainability } \\
\text { when evaluating researchers and research teams; } \\
\text { - Enhance accountability of researchers and research } \\
\text { teams; }\end{array}$ & $\begin{array}{l}\text { - Modification of career evaluation criteria by including inter- and trans-disciplinary } \\
\text { initiatives; } \\
\text { - Develop criteria for evaluation and reporting of inter- and trans-disciplinary elements in } \\
\text { project proposals; } \\
\text { - Sustainability commission replaces/complements ethical commission; } \\
\text { - Development of common output indicators for sustainability relevance; } \\
\text { - Awards in support of 'research for sustainability' }\end{array}$ \\
\hline $\begin{array}{l}\text { Research } \\
\quad \text { organization }\end{array}$ & - Operationalize trans-disciplinarity; & $\begin{array}{l}\text { - Engagement of non-academic actors in the assessment of research activities; } \\
\text { - Support the establishment and activities of inter-disciplinary research platforms/hubs; } \\
\text { - Organize common interdisciplinary events/project calls with(in) such platforms; } \\
\text { - Set up a sustainability science chair/professorship; } \\
\text { - Development of an action plan for engaging non-academic actors (businesses, cities, .) in } \\
\text { research for sustainability; } \\
\text { - Development of inter-institutional centers of excellence in research for sustainability; } \\
\text { - Stimulate inter-disciplinary master theses (joint problem statement; thesis award); } \\
\text { - Taking stock of 'research for sustainability' activities within the institution; } \\
\text { - Appointment of research coordinator(s) for drafting and managing inter- and trans- } \\
\text { disciplinary project proposals. }\end{array}$ \\
\hline $\begin{array}{l}\text { Capacity } \\
\text { building }\end{array}$ & $\begin{array}{l}\text { - Strengthen capacity w.r.t. (inter- and transdisciplinary) } \\
\text { research for sustainability }\end{array}$ & $\begin{array}{l}\text { - Exchange of good practices by way of regular inter-institutional consultation; } \\
\text { - Focus on problem-driven education in preparation of future (research) career (e.g. Mas- } \\
\text { terclass sustainability science for PhD students \& postdoctoral researchers); } \\
\text { - Operationalization of sustainability for different researchers and research teams by way of } \\
\text { listing possible research actions; } \\
\text { - Promotion \& recognition of academic leadership w.r.t. inter- and transdisciplinary } \\
\text { approach of 'wicked' societal challenges; }\end{array}$ \\
\hline Policy & $\begin{array}{l}\text { - Anchoring research for sustainability in the institution } \\
\text { - Increase visibility of research for sustainability }\end{array}$ & $\begin{array}{l}\text { - Integration of a commitment towards research for sustainability in mission and vision } \\
\text { statements; } \\
\text { - Integration of 'research for sustainability' commitment in a code of conduct for researchers; } \\
\text { - Granting recognition (e.g doctor honoris causa titles) to sustainability scientists; } \\
\text { - Adjusting communication: reframing press releases towards challenge-driven } \\
\text { communication; } \\
\text { - Adjusting the core business of higher education institutions to the changed pattern of } \\
\text { expectations from society: } \\
\text { - Enhancing the linkages between 'research for sustainability' actions and actions for } \\
\text { sustainability integration in campus operations and in curricula; } \\
\text { - Inclusion of sustainability as a criterion in calls for tender; } \\
\text { - Support for organizational and cultural change towards trans-and interdisciplinary action- } \\
\text { driven research; }\end{array}$ \\
\hline
\end{tabular}

creating forums (or 'arenas') of frontrunners that develop a system analysis and a future visions and set up transition paths with experiments.

'Transition UGent' organized dozens of roundtable exercises between 2012 and 2014 to develop system analyses, visions and transition paths on nine fields of action of Ghent University, including research. We focus on the transition pathway that was developed for research (see Fig. 3).

Based on the numerous participatory roundtable exercises, the following transition path for research was developed at Ghent University. Starting with a critical analysis of the situation in 2012 a stepwise transition path for 2013-2017 was proposed with 2020 as time horizon. The university-wide obstacles identified in early 2013 included: the compartmentalization of research, the lack of student involvement in research; the lack of cooperation with business and government; the lack of focus on societal relevance; the outputdriven research culture ('publish or perish'). In 2020, the stated objectives (which are arguably yet purposely broad) are: to focus on socio-ecological challenges, to use societal relevance as a key criterion for research, to be in a situation where multi-, inter- and transdisciplinary research is considered mainstream, and to perform research sustainably.

The actions proposed by the Ghent University Transition Initiative bear resemblance with the generic actions proposed by the workshop participants (listed in Section 4) despite the absence of any formal linkages between both initiatives. The Ghent University case does devote explicit attention to the implementation of transdisciplinarity and, as such, started an experiment at the end of 2015: a platform on sustainable cities where about 20 academics from different disciplines and about 20 policymakers from the city of Ghent try to build a knowledge platform on wicked issues. In doing so, the city of Ghent functions as a 'living lab' for researchers and municipal actors can make a more effective use of the academic expertise of Ghent University. This platform crosses traditional boundaries at three levels: within the university, as it crosses disciplinary boundaries; within the municipal authorities; and between the city and academia. The first results of this experimental platform which embodies a sustainability-oriented coproduction of knowledge-approach, are expected in 2017. The shared sense of ownership of sustainability research initiatives is 


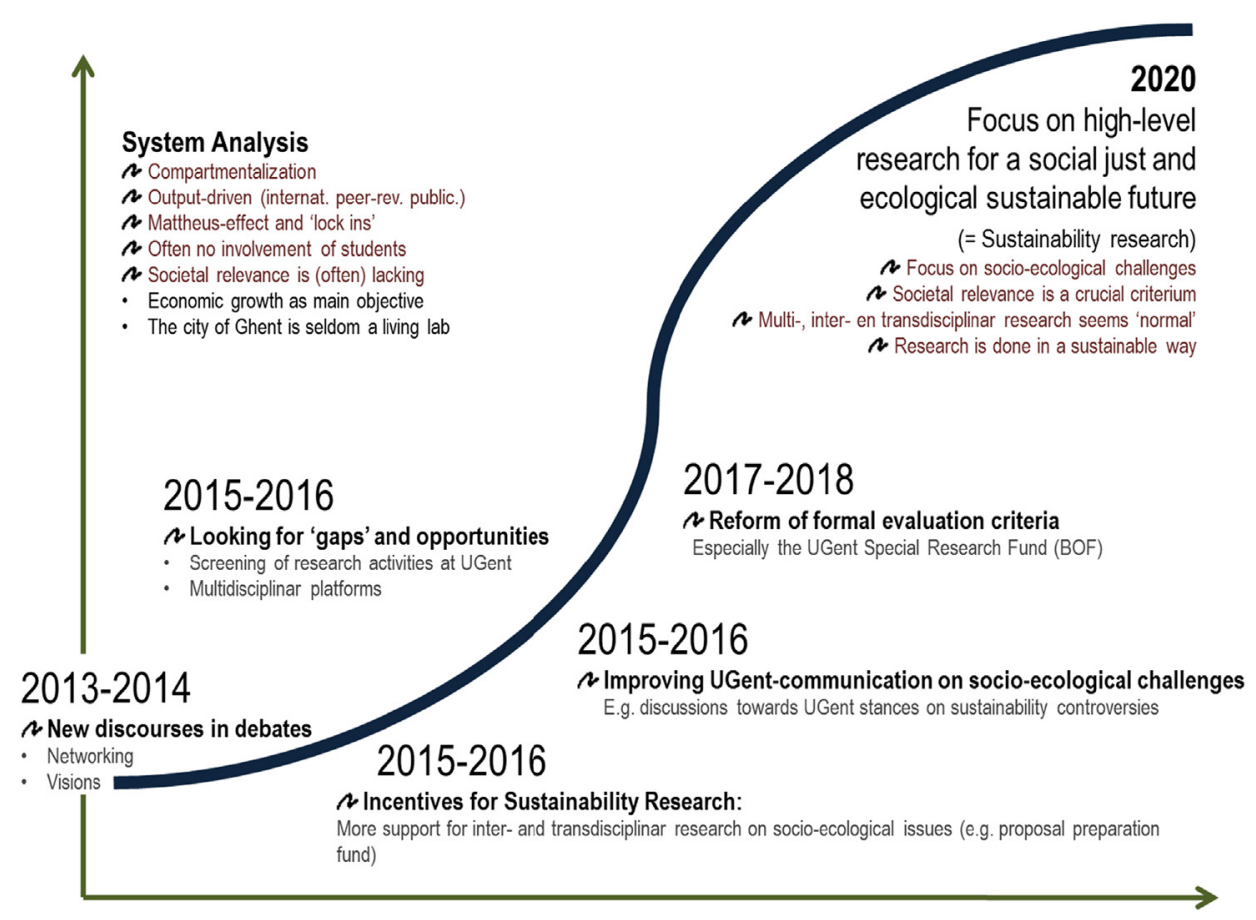

Fig. 3. Transition path on 'research' as developed by the Ghent University Transition Initiative (Transition UGent).

hence developing in the Ghent area, as are other collaborative research experiments (Devolder and Block, 2015). Ghent University's proposed adjustment of the university's assessment system and career evaluation also provides an interesting first step in implementing sustainability in academic research. It emphasizes the fact that there is no need to wait until regional/national-level funding channels have been reformed - individual higher education institutions can take the lead by reforming their own assessment and funding systems. Increased visibility and communication are stressed both to inform the internal university staff and to showcase the unicity of sustainability innovations, the latter objective mainly targeting external actors (potential students and (non-)academic research partners). While an awareness of context specificities is key, the initiatives proposed by Ghent University are at least partly transferable to other higher education institutions, ideally as part of a broader change movement towards -academicsustainability (see also Adomssent et al., 2007).

\section{Conclusion}

By proposing a range of actions allowing to implement sustainability in academic research, this study contributes to the translation of this broad, contested yet workable concept. These actions (see Table 2) are compiled based on a combination of an explorative literature review, a workshop involving research managers and other experts, and a critical reflection on a university-specific case study. While acknowledging the limitations of this study (which included only one case study, and which does not include a long-term study on evolving interpretations of sustainability in an academic context), the combination of approaches to achieve a multidimensional conceptualization of sustainability in academic research provides a way to bridge the divide between discourse and practice.

Actions for sustainability in academic research cannot be performed in a contextual 'vacuum': although every individual higher education institution can move forward by progressively realizing a selected set of actions, this major organizational and cultural change process is faced with challenges.

There are multiple reasons why implementing research for sustainability remains a challenge despite the growing acknowledgement of the importance of this key aspect of 'sustainability in higher education'. The first reason relates to the intrinsic multiinterpretability of the sustainability concept itself. The second reason pertains to academic freedom. Steering research in a particular direction, even if that direction is presented as pointing to the 'consensual' realization of sustainability, inevitably raises questions about the independence of the researcher and the fear of limitations that could be imposed on academic freedom. The third reason relates to the specificity of every research tradition and the interpretation given to 'science and research for sustainability', as outlined in the literature review. Applied science can have positive effects on sustainability even without consciously following a selfreflexive, transdisciplinary approach, while the implications of fundamental research for sustainability are often impossible to predict. Despite these caveats, higher education institutions can move forward in actively shaping the contours of 'research for sustainability', in facilitating experiments (e.g. by following the transition logic where successful niche practices can be generalized in time) and in designing actions ranging from new ways of funding research to new career and research evaluation frameworks. Opportunities for research complementing traditional Mode 1 science should be actively fostered. There is no need for a full overhaul, but there is need for a readjustment and an open-minded approach towards the guiding principles of science for sustainability.

When comparing the generic actions proposed during the expert workshop with the concrete steps taken by Ghent University in a university-specific initiative, many commonalities can be identified. Differences in emphasis surface regarding the implementation of transdisciplinarity, while a pragmatic step-by-step approach is advocated in the adjustment of funding and assessment of research for sustainability. The fact that individual higher education institutions do not control all levers of influence regarding research funding does not mean that no actions can be taken. The process of gradual change towards adequately funding 
research for sustainability will be a shared responsibility of government and private actors in the long run. Clarifying the meaning and the implications of sustainability for academic research is a multi-actor endeavor.

Further research on the applicability of the proposed actions and on the transferability of university-specific experiences is needed. Particularly relevant topics include the definition and measurement of the effectiveness of the different types of actions; the financial, time and human resources required to support any of these actions; and the dynamic interpretations of what research for sustainability means among a wide range of stakeholders and institutions. While the present study provides building blocks for the realization of academic research for sustainability, the huge transformation needed to assess and upscale experiments and pilot actions requires sustained efforts from academics and external actors alike. Exchanging ideas and potential best practices as well as clarifying terminology and objectives are essential first steps forward.

\section{Acknowledgements}

$\mathrm{JH}$ is funded by the Belgian National Research Foundation (FRSFNRS). TW is funded by the Flemish Inter-University Research Council (VLIR-UOS), 1220215F. We acknowledge the support of the Flemish Government's Department of Environment \& Energy's 'Ecocampus' program.

\section{References}

Adomssent, M., Godemann, H., Michelsen, G., 2007. Transferability of approaches to sustainable development at universities as a challenge. Int. J. Sustain. High. Educ. 8, 385-402.

Aktas, C.B., 2015. Reflections on interdisciplinary sustainability research with undergraduate students. Int. J. Sustain. High. Educ. 16, 354-366.

Andersson, K., 2008. Transparency and Accountability in Science and Politics - the Awareness Principle. Palgrave MacMillan, Basingstoke, United Kingdom and New York, United States of America.

Baumgartner, R.J., 2011. Critical perspectives of sustainable development research and practice. J. Clean. Prod. 19, 783-786.

Beynaghi, A., Moztarzadeh, H., Maknoon, R., Waas, T., Mozafari, M., Hugé, J., Leal Filo, W., 2014. Towards an orientation of higher education in the post Rio +20 process: how is the game changing? Futures 63, 49-67.

Biggs, D., Biggs, R.O., Dakos, V., Scholes, R., Schoon, M., 2011. Are we entering an era of concatenated global crises? Ecol. Soc. 16, 27.

Binder, C.R., Absenger-Helmli, I., Schilling, T., 2015. The reality of transdisciplinarity: a framework-based self-reflection from science and practice leaders. Sustain. Sci. 10, 545-562.

Blanchard, A., Vanderlinden, J.P., 2010. Dissipating the fuzziness around interdisciplinarity: the case of climate change research. Sapiens 3 (1), 65-70.

Boulanger, P.M., Bréchet, T., 2005. Models for policy-making in sustainable development: the state of the art and perspectives for research. Ecol. Econ. 55 $337-350$.

Brandt, P., Ernst, A., Gralla, F., Luederitz, C., Lang, D.J., Newig, J., Reinert, F., Abson, D.J., van Wehrden, H., 2013. A review of transdisciplinary research in sustainability science. Ecol. Econ. 92, 1-15.

Clark, W.C., 2007. Sustainability science: a room of its own. PNAS 104, 1737-1738.

Cornell, S., Berkhout, F., Tuinstra, W., Tàbara, J.D., Jäger, J., Chabay, I., de Wit, B. Langlais, R., Mills, D., Moll, P., Otto, I.M., Petersen, A., Pohl, C., Kerkhoff, L., 2013. Opening up knowledge systems for better responses to global environmental change. Environ. Sci. Policy 28, 60-70.

Costa, S., Scoble, M., 2006. An interdisciplinary approach to integrating sustainability into mining engineering education and research. J. Clean. Prod. 14, 366-373.

Dentoni, D., Bitzer, V., 2014. The role(s) of universities in dealing with global wicked problems through multi-stakeholder initiatives. J. Clean. Prod. 106, 68-78.

Devolder, S., Block, T., 2015. Transition thinking incorporated: towards a new discussion framework on sustainable urban projects. Sustainability 7, 3269-3289.

Dietz, S., Neumayer, E., 2007. Weak and strong sustainability in the SEEA: concepts and measurements. Ecol. Econ. 61, 617-626.

Ferrer-Balas, D., Lozano, R., Huisingh, D., Buckland, H., Ysern, P., Zilahy, G., 2010. Going beyond the rhetoric: system-wide changes in universities for sustainable societies. J. Clean. Prod. 18, 607-610.

Fien, J., 2002. Advancing sustainability in higher education: issues and opportunities for research. Int. J. Sustain. High. Educ. 3 (3), 343-353.

Friibergh Workshop on Sustainability Science. Sustainability science: Statement of the Friibergh Workshop on Sustainability Science. http://live.belfercenter.org/ publication/12783/sustainability_science.html. Last accessed February 29, 2000.

Funtowicz, S.O., Martinez-Allier, J., Munda, G., Ravetz, J.R., 1999. Information Tools for Environmental Policy under Conditions of Complexity. Environmental Issues Series 9. European Environmental Agency, Copenhagen. Denmark.

Gardner, S.K., 2013. Paradigmatic differences, power and status: a qualitative investigation of faculty in one interdisciplinary research collaboration on sustainability science. Sustain. Sci. 8, 241-252.

Gaziulusoy, A.I., Ryan, C., McGrail, S., Chandler, P., Twomey, P., 2015. Identifying and addressing challenges faced by transdisciplinary research teams in climate change research. J. Clean. Prod. 123, 55-64. http://dx.doi.org/10.1016/ j.jclepro.2015.08.049.

Geels, F.W., 2002. Technological transitions as evolutionary reconfiguration processes: a multi-level perspective and a case study. Res. Policy 31, 1257-1274.

Ghent University, 2014. Transition University of Ghent. Memorandum (in Dutch). Last accessed on February 26, 2016. https://issuu.com/universiteitgent/docs/ memorandum_transitie_ugent_2014/0.

Ghent University, 2015. Rankings of Universities. Last accessed on February 26, 2016. http://www.ugent.be/en/ghentuniv/presentation/rankings.htm.

Gibbons, M., 1999. Science's new social contract with society. Nature 402, C81-C85.

Griggs, D., Stafford-Smith, M., Gaffney, O., Rockstrom, J., Ohman, M.C., Shyamsundar, P., Stffen, W., Glaser, G., Kanie, N., Noble, I., 2013. Sustainable development goals for people and planet. Nature 495, 305-307.

Grist, N., 2008. Positioning climate change in sustainable development discourse. J. Int. Dev. 20, 783-803.

Hessels, L.K., van Lente, H., 2008. Re-thinking new knowledge production: a literature review and a research agenda. Res. Policy 37, 740-760.

Hoover, E., Harder, M.K., 2015. What lies beneath the surface? the hidden complexities of organizational change for sustainability in higher education, J. Clean. Prod. 106, 175-188.

Hoppe, R., 2010. From knowledge use towards boundary work: sketch of an emerging new agenda for inquiry into science-policy interaction. In: in 't Veld, R.J. (Ed.), Knowledge Democracy, pp. 169-186.

Hopwood, W., Mellor, M., O'Brien, G., 2005. Sustainable development: mapping different approaches. Sustain. Dev. 13, 38-52.

Hugé, J., Waas, T., Dahdouh-Guebas, F., Koedam, N., Block, T., 2013. A discourseanalytical perspective on sustainability assessment: interpreting sustainable development in practice. Sustain. Sci. 8, 187-198.

Hulme, D., Toye, J., 2006. The case for cross-disciplinary social science research on poverty, inequality and well-being. J. Dev. Stud. 42, 1085-1107.

Jain, S., Aggarwal, P., Sharma, N., Sharma, P., 2013. Fostering sustainability through education, research and practice: a case study of TERI University. J. Clean. Prod. $61,20-24$.

Jänicke, M., 2007. Evaluation for sustainable development: the Rio model of governance. In: George, C., Kirkpatrick, C. (Eds.), Impact Assessment and Sustainable Development - European Practice and Experience. Edward Elgar Publishing, Cheltenham, United Kingdom \& Northampton, United States of America.

Jasanoff, S., 2004. States of Knowledge. The Coproduction of Science and Social Order. Routledge, London, UK and New York, USA.

Kastenhofer, K., Bechtold, U., Wilfing, H., 2011. Sustaining sustainability science: the role of established inter-disciplines. Ecol. Econ. 70, 835-843.

Kates, R.W., Clark, W.C., Corell, R., Hall, M.J., Jaeger, C.C., Lowe, I., McCarthy, J.J., Schellnhuber, H.J., Bolin, B., Dickson, N.M., Faucheux, S., Gallopin, G.C., Grübler, A., Huntley, J., Jäger, J., Jodha, N.S., Kasperson, R.E., Mabogunje, A. Matson, P., Mooney, H., Moore III, B., O'Riordan, T., Svedin, U., 2001. Sustainability science. Science 292, 641-642.

Kemp, R., Martens, P., 2007. Sustainable Development: how to manage something that is subjective and never can be achieved. Sustain. Sci. Pract. Policy 3 (2), $5-14$.

Khalili, N.R., Duecker, S., Ashton, W., Chavez, F., 2015. From cleaner production to sustainable development: the role of academia. J. Clean. Prod. 96, 30-43.

Kohtala, C., 2015. Addressing sustainability in research on distributed production: an integrated literature review. J. Clean. Prod. 106, 654-668.

Lafferty, W.M., Meadowcroft, J., 2000. Implementing Sustainable Development. Strategies and Initiatives in High Consumption Societies. Oxford University Press, New York, USA.

Lang, D.J., Wiek, A., Bergmann, M., Stauffacher, M., Martens, P., Moll, P., Swilling, M., Thomas, C.J., 2012. Transdisciplinary research in sustainability science: practice, principles and challenges. Sustain. Sci. 7, 25-43.

Loorbach, D., 2007. Transition Management, New Mode of Governance for Sustainable Development. International Books. Utrecht, The Netherlands.

Lozano, R., Ceulemans, K., Alonso-Almeida, M., Huisingh, D., Lozano, F.J., Waas, T., Lambrechts, W., Lukman, R., Hugé, J., 2014. A review of commitment and implementation of sustainable development in higher education: results from a worldwide survey. J. Clean. Prod. 108, 1-18.

Lukman, R., Krajnc, D., Glavic, P., 2009. Fostering collaboration between universities regarding regional sustainability initiatives: the University of Maribor. J. Clean. Prod. 12, 1143-1153.

Luks, F., Siebenhüner, B., 2007. Transdisciplinarity for social learning? the contribution of the German socio-ecological research initiative to sustainability governance. Ecol. Econ. 63, 418-426.

Manring, S.L., 2014. The role of universities in developing interdisciplinary action research collaborations to understand and manage resilient social-ecological systems. J. Clean. Prod. 64, 125-135. 
McCormick, K., Neij, L., Mont, O., Ryan, C., Rodhe, H., Orsato, R., 2016. Advancing sustainable solutions: an interdisciplinary and collaborative research agenda. J. Clean. Prod. 123, 1-4. http://dx.doi.org/10.1016/j.jclepro.2016.01.038.

Miller, T.R., 2013. Constructing sustainability science: emerging perspectives and research trajectories. Sustain. Sci. 8, 279-293.

Miller, T.R., Wiek, A., Sarewitz, D., Robinson, J., Olsson, L., Kriebel, D., Loorbach, D., 2014. The future of sustainability science: a solutions-oriented research agenda. Sustain. Sci. 9, 239-246.

Müller, A., 2003. A flower in full blossom? Ecological economics at the crossroads between normal and post-normal science. Ecol. Econ. 45, 19-27.

Nevens, F., Roorda, C., 2014. A climate of change: a transition approach for climate neutrality in the city of Ghent (Belgium). Sustain. Cities Soc. 10, 112-121.

Nowotny, H., Scott, P., Gibbons, M., 2001. Re-thinking Science-knowledge and the Public in an Age of Uncertainty. Polity Press, Cambridge. United Kingdom.

Nowotny, H., Scott, P., Gibbons, M., 2003. Introduction: 'Mode 2 revisited: the new production of knowledge'. Minerva 41, 179-194.

Ostrom, E., 2009. A general framework for assessing the sustainability of socioecological systems. Science 325, 419-422.

Peer, V., Stoeglehner, V., 2013. Universities as change agents for sustainability framing the role of knowledge transfer and generation in regional development processes. J. Clean. Prod. 44, 85-95.

Perrings, C., 2007. Future challenges. In: Proceedings of the National Academy of Sciences (PNAS) USA, pp. 15179-15180.

Polk, M., 2014. Achieving the promise of transdisciplinarity: a critical exploration of the relationship between transdisciplinary research and societal problem solving. Sustain. Sci. 9, 439-451.

Popa, F., Guillermin, M., Dedeurwaerdere, T., 2015. A pragmatist approach to transdisciplinarity in sustainability research: from complex systems theory to reflexive science. Futures 65, 45-56.

Pope, J., Annandale, D., Morrison-Saunders, A., 2004. Conceptualizing sustainability assessment. Environ. Impact Assess. Rev. 24, 595-616.

Posch, A., Scholz, R.W., 2006. Transdisciplinary case studies for sustainability learning. Int. J. Sustain. High. Educ. 7 (3).

Quental, N., Lourenço, J.M., Nunes da Silva, F., 2009. Sustainable development policy: goals, targets and political cycles. Sustain. Dev. 19, 15-29.

Ramos, T., Caeiro, S., van Hoof, B., Lozano, R., Huisingh, D., Ceulemans, K., 2015. Experiences for the implementation of sustainable development in higher education institutions: environmental Management for Sustainable Universities. J. Clean. Prod. 106, 3-10.

Robinson, J., 2004. Squaring the circle? Some thoughts on the idea of sustainable development. Ecol. Econ. 48, 369-384.

Rosenau, J., 2005. Globalisation and governance - sustainability between fragmentation and integration. In: Petschow, U., Rosenau, J., Von Weiszäcker, E.U. (Eds.), Governance and Sustainability. GreenLeaf Publishing, Sheffield, United Kingdom.

Runhaar, H., 2009. Putting SEA in context: a discourse perspective on how SEA contributes to decision-making. Environ. Impact Assess. Rev. 29, 200-209.

Sabau, G.L., 2010. Know, live and let live: towards a redefinition of the knowledgebased economy-sustainable development nexus. Ecol. Econ. 69, 1193-1201.

Sauvé, S., Bernard, S., Sloan, P., 2015. Environmental sciences, sustainable development and circular economy: alternative concepts for trans-disciplinary research. Environ. Dev. 17, 48-56. http://dx.doi.org/10.1016/ j.envdev.2015.09.002.

Schoolman, E.D., Guest, J.S., Bush, K.F., Bell, A.R., 2012. How interdisciplinary is sustainability research? Analyzing the structure of an emerging scientific field. Sustain. Sci. 7, 67-80.

Scott, A., 2011. Focussing in on focus groups: effective participative tools or cheap fixes for land use policy? Land Use Policy 28, 684-694.

Steffen, W., Grinevald, J., Crutzen, P., McNeill, J., 2011. The Anthropocene: conceptual and historical perspectives. Philosophical Trans. R. Soc. 369, 842-867.

Steffen, W., Richardson, K., Rockstrom, J., Cornell, S.E., Fetzer, I., Bennett, E.M., Biggs, R., Carpenter, S.R., de Vries, W., de Wit, C.A., Folke, C., Gerten, D. Heinke, J., Mace, G.M., Persson, L.M., Ramanathan, V., Reyers, B., Sörlin, S., 2015 Planetary boundaries: guiding human development on a changing planet. Science 347 (6223).

Stock, P., Burton, R.J.F., 2011. Defining terms for integrated (multi-, inter-, transdisciplinary) sustainability research. Sustainability 3, 1090-1113.

Sustainability Exchange, 2015. Transition Ghent University. Innovation Think Tank for Sustainable Development. Last accessed February 25, 2016. http://www. sustainabilityexchange.ac.uk/files/transition_ghent_university.pdf.

Sylvestre, P., McNeill, R., Wright, T., 2013. From Talloires to Turin: a critical discourse analysis of declarations for sustainability in higher education. Sustainability 5 , 1356-1371.

Sylvestre, P., Wright, T., Sherren, K., 2014. A tale of two (or more) sustainabilities: a Q methodology study of university professors' perspectives on sustainable universities. Sustainability 6, 1521-1543.

Trenchner, G.P., Yarimu, M., Kharrazi, A., 2013. Co-creating sustainability: crosssector university collaborations for driving sustainable urban transformations. J. Clean. Prod. 50, 40-55.

United Nations 2015. https://sustainabledevelopment.un.org/Last accessed November 3rd, 2015.

Van Asselt, M., Rijkens-Klomp, N., 2002. A look in the mirror: reflection on participation in Integrated Assessment from a methodological perspective. Glob. Environ. Change 12, 167184.

van Breda, J., Musango, J., Brent, A., 2016. Undertaking individual transdisciplinary PhD research for sustainable development: case studies from South Africa. Int. J. Sustain. High. Educ. 17, 150-166.

van Zeijl-Rozema, A., Cörvers, R., Kemp, R., Martens, P., 2008. Governance for sustainable development: a framework. Sustain. Dev. 16 (6), 410-421.

Waas, T., Verbruggen, A., Wright, T., 2010. University research for sustainable development: definition and characteristics explored. J. Clean. Prod. 18, 629-636.

Waas, T., Hugé, J., Verbruggen, A., Wright, T., 2011. Sustainable development: a bird's eye view. Sustainability 3, 1637-1661.

Wals, A., Jickling, B., 2002. Sustainability in higher education. From doublethink and newspeak to critical thinking and meaningful learning. Int. J. Sustain. High. Educ. 3 (3), 221-232.

Wiek, A., Withycombe, L., Redman, C.L., 2011. Key competencies in sustainability: a reference framework for academic program development. Sustain. Sci. 6, 203-218.

Wittmayer, J.M., Schäpke, N., 2014. Action, research and participation: role of researchers in sustainability transitions. Sustain. Sci. 9, 483-496.

Wooltorton, S., Wilkinson, A., Horwitz, P., Bahn, S., Redmond, J., Dooley, J., 2015 Sustainability and action research in universities: towards knowledge for organizational transformation. Int. J. Sustain. High. Educ. 16, 424-439.

World Commission on Environment and Development, 1987. Our Common Future. Published as Annex to the General Assembly Document A/42/427. United Nations.

Wright, T.S.A., Wilton, H., 2012. Facilities management directors' conceptualizations of sustainability in higher education. J. Clean. Prod. 31, 118-125.

Wuelser, G., 2014. Towards adequately framing sustainability goals in research projects: the case of land use studies. Sustain. Sci. 9, 263-276.

Wuelser, G., Pohl, C., Hirsch Hadorn, G., 2012. Structuring complexity for tailoring research contribution to sustainable development: a framework. Sustain. Sci. 7, 81-93.

Zanotti, L., Palomino-Schalscha, M., 2016. Taking different ways of knowing seriously: cross-cultural work as translations and multiplicity. Sustain. Sci. 11, $139-152$. 